\title{
Evidence of horizontal and vertical transport of water in the Southern Hemisphere tropical tropopause layer (TTL) from high-resolution balloon observations
}

Sergey M. Khaykin ${ }^{1}$, Jean-Pierre Pommereau ${ }^{1}$, Emmanuel D. Riviere ${ }^{2}$, Gerhard Held ${ }^{3,}$, Felix Ploeger ${ }^{4}$, Melanie Ghysels $^{2, \mathrm{a}}$, Nadir Amarouche ${ }^{5}$, Jean-Paul Vernier ${ }^{6,7}$, Frank G. Wienhold ${ }^{8}$, and Dmitry Ionov ${ }^{9}$

${ }^{1}$ LATMOS, CNRS, Université de Versailles St Quentin, Guyancourt, France

${ }^{2}$ GSMA, Université de Reims Champagne Ardenne and CNRS, Reims, France

${ }^{3}$ Instituto de Pesquisas Meteorológicas (IPMet), UNESP, Bauru, S.P., Brazil

${ }^{4}$ Forschungszentrum Jülich, IEK-7, Jülich, Germany

${ }^{5}$ Division Technique de l'INSU, CNRS, Meudon, France

${ }^{6}$ Science Systems and Applications, Inc, Hampton, Virginia, USA

${ }^{7}$ NASA Langley Research Center, Hampton, Virginia, USA

${ }^{8}$ ETH Zurich, Institute for Atmospheric and Climate Science, Zurich, Switzerland

${ }^{9}$ St. Petersburg State University, St. Petersburg, Russian Federation

${ }^{a}$ now at: National Institute of Standards and Technology, Gaithersburg, MD, USA

*retired

Correspondence to: Sergey M. Khaykin (sergey.khaykin@latmos.ipsl.fr)

Received: 8 July 2016 - Published in Atmos. Chem. Phys. Discuss.: 18 July 2016

Revised: 13 September 2016 - Accepted: 19 September 2016 - Published: 29 September 2016 pact Optical Backscatter Aerosol Detector) sondes, complemented by Vaisala RS92 radiosondes. Water vapour vertical profiles obtained independently by the two stratospheric hygrometers are in excellent agreement, ensuring credibility of the vertical structures observed.

A signature of in-mixing is inferred from a series of vertical profiles, showing coincident enhancements in water vapour (of up to $0.5 \mathrm{ppmv}$ ) and aerosol at the $425 \mathrm{~K}$ (18.5 km) level. Trajectory analysis unambiguously links these features to intrusions from the Southern Hemisphere extratropical stratosphere, containing more water and aerosol, as demonstrated by MLS and CALIPSO global observations. The in-mixing is successfully reproduced by CLaMS simulations, showing a relatively moist filament extending to $20^{\circ} \mathrm{S}$. A signature of local cross-tropopause transport of water is observed in a particular sounding, performed on a convective day and revealing water vapour enhancements of up to $0.6 \mathrm{ppmv}$ as high as the $404 \mathrm{~K}(17.8 \mathrm{~km})$ level. These are shown to originate from convective overshoots upwind detected by an S-band weather radar operating locally in Bauru. 
The accurate in situ observations uncover two independent moisture pathways into the tropical lower stratosphere, which are hardly detectable by space-borne sounders. We argue that the moistening by horizontal transport is limited by the weak meridional gradients of water, whereas the fast convective cross-tropopause transport, largely missed by global models, can have a substantial effect, at least at a regional scale.

\section{Introduction}

The tropical tropopause layer (TTL) is a region of transition between tropospheric convective and stratospheric radiative regimes. Extending between the main level of convective outflow $(\sim 14 \mathrm{~km})$ and the maximum level reachable by convection $(18-19 \mathrm{~km})$, the TTL sets the boundary conditions for the composition of air entering the global stratosphere (Fueglistaler et al., 2009). Accurate knowledge of the TTL physical processes and their interplay is thus of key importance for understanding climate change (Randel and Jensen, 2013). The role of stratospheric water vapour in global surface climate is now well recognised (Solomon et al., 2010; Riese et al., 2012; Dessler et al., 2013), evoking the need to better constrain the TTL processes governing the entry level of stratospheric water vapour.

There are three transport processes controlling the water vapour abundance in the TTL, thereby setting the global stratospheric water budget: (1) slow ascent in the upward branch of the Brewer-Dobson circulation leading to dehydration of air passing through the coldest regions of the TTL (2) fast cross-tropopause vertical transport (convective overshooting) and (3) quasi-horizontal transport from the extratropics (in-mixing). The dehydration (freeze-drying) along the slow ascent or advection occurs primarily in the western Pacific and maritime continent ("cold trap" hypothesis) - a region of large-scale slow ascent and cold TTL anomaly (Holton and Gettelman, 2001), where the cold-point tropopause (CPT) temperatures experience minimum during austral summer (Gettelman and Forster, 2002).

While the dehydration process followed by upward and poleward transport of dry air is generally deemed to be of primary importance for the mean stratospheric water concentration and seasonality, the effect of overshooting convection on the TTL water vapour (dehydration vs. moistening and the net effect) has been under debate for many years (Randel and Jensen, 2013). There is a growing amount of observational evidence that overshooting convection, injecting material directly into the uppermost TTL has a moistening effect on the lower stratosphere (Kelly et al., 1993; Corti et al., 2008; Khaykin et al., 2009; de Reus et al., 2009; Schiller et al., 2009; Sargent et al., 2014). Consistent with the observations, simulations of overshooting events using cloudresolving modelling show significant localised moistening of the lower stratosphere (Chaboureau et al., 2007; Jensen et al., 2007; Grosvenor et al., 2007; Chemel et al., 2009; Liu et al., 2010). A dehydrating effect of overshooting may occur only if the TTL is initially supersaturated with respect to ice, as concluded by Jensen et al. (2007). In contrast to that, Randel et al. (2015) found that enhanced tropospheric convection within Asian and North American monsoons leads to reduced stratospheric water vapour. While upscaling the overshooting events and quantifying their net effect on water vapour remains a difficult task, various space-borne observations suggest that the most vigorous convection, capable of direct transport of material into the lower stratosphere, is mostly restricted to the tropical land regions (Liu and Zipser, 2005; Ricaud et al., 2009; Iwasaki et al., 2010; Bergman et al., 2012; Khaykin et al., 2013a; Carminati et al., 2014).

Another important contributor to the composition of the TTL is the horizontal (isentropic) transport from the extratropical lower stratosphere (in-mixing), the significance of which is pointed out in a number of model- and observationbased studies (Marcy et al., 2007; Konopka et al., 2009; Homan et al., 2010; Ploeger et al., 2012; Sargent et al., 2014). The in-mixing into the TTL is mostly driven by the anticyclonic circulation of the large monsoon systems in both hemispheres. The strongest Asian monsoon is considered responsible for the boreal summer maximum of in-mixing from the Northern Hemisphere (Konopka et al., 2009), whereas in the Southern Hemisphere, the in-mixing peaks in February (Ploeger et al., 2012). The net fraction of in-mixed air varies between 5 and $20 \%$ according to Ploeger et al. (2012) and appears most apparent in tracers with stratospheric origins and strong latitudinal gradients, such as $\mathrm{O}_{3}$ and $\mathrm{HCl}$ (Marcy et al., 2007). Based on the transport model simulations, the effect of in-mixing on stratospheric water is expected to be limited due to a small latitudinal gradient of this trace gas, although this inference has not been yet verified observationally.

Transport processes influencing the TTL composition, be they slow ascent, fast overshooting or horizontal in-mixing, have been mainly studied using trajectory and mesoscale modelling, whereas in situ observational evidence, indispensable to constrain the models, is lacking. Satellite observations, providing a global perspective, are not capable of resolving kilometre-scale vertical distribution of gases in the TTL, thus missing the signatures of transport processes.

This paper presents in situ observational evidence of the coexistence of the two out of three transport mechanisms described above - convective overshooting and in-mixing detected by accurate high-resolution balloon-borne measurements of water vapour, methane and aerosol in the TTL above Bauru, Brazil $\left(22^{\circ} \mathrm{S}\right)$ in March 2012. Satellite measurements, radar acquisitions and trajectory/transport modelling are used to interpret the origin of vertical structures observed in situ. The paper is organised as follows: Sect. 2 provides a description of experimental set-up, instrumentation used and models exploited. Sections 3 and 4 describe the 
observations of horizontal and vertical transport signatures respectively. Section 5 discusses the relative importance of both transport mechanisms and summarises the paper.

\section{Experimental set-up, instrumentation and modelling}

A French-funded project named TRO-Pico aimed at characterising the variability and frequency of convective water injections, their contribution at the regional wet season timescale and improving the understanding of their role with respect to the cold trap at a wider scale. The project included two intensive balloon campaigns held in FebruaryMarch 2012 and January-February 2013 under the auspices of the Brazilian Meteorological Research Institute (IPMet), Universidade Estadual Paulista (UNESP), located in Bauru, São Paolo, Brazil $\left(22.36^{\circ} \mathrm{S}, 49.03^{\circ} \mathrm{W}\right)$. The present study is based on the balloon experiments conducted during the first deployment in 2012, which included seven flights of Raven Aerostrar zero pressure plastic balloons of 500 and $1500 \mathrm{~m}^{3}$ and six flights of Totex $1200 \mathrm{~g}$ rubber balloons. The plastic balloon payloads included Pico-SDLA instruments for water vapour and methane measurements whereas the rubber balloons were carrying lightweight FLASH-B and COBALD sondes for measurement of water vapour and aerosol backscatter respectively. The thermodynamical data were provided by Vaisala RS92 radiosondes integrated in the payload.

On 13 March 2012, a rubber balloon payload (FLASH$\mathrm{B}+\mathrm{COBALD}$ ) was flown in parallel with a plastic balloon payload (Pico-SDLA $\mathrm{H}_{2} \mathrm{O}$ ), which provided quasisimultaneous measurements of water vapour using two hygrometers. Point-by-point intercomparison of the obtained water vapour profiles (Ghysels et al., 2016) showed excellent agreement with a mean difference above $15 \mathrm{~km}$ of $0.5 \%$ $(0.02 \pm 0.21 \mathrm{ppmv})$.

\subsection{Balloon-borne in situ instruments}

Fluorescence Lyman-Alpha Stratospheric Hygrometer for Balloon (FLASH-B) is a compact lightweight sonde developed at the Central Aerological Observatory of Roshydromet, Russia for water vapour measurements in the upper troposphere and stratosphere (Yushkov et al., 1998). The instrument uses an open coaxial optical layout, where the analysed volume is located outside the instrument. This allows the size of the instrument to be reduced to a small sonde with a total weight of about $1 \mathrm{~kg}$ including batteries but restricts its application to night-time. The typical precision of the hygrometer in the stratosphere is 5-6\%, whereas the total uncertainty, including the calibration error is estimated to be below $10 \%$. This estimate is rather conservative as suggested by comparisons with other water vapour instruments, showing discrepancies below 5\% (Khaykin et al., 2013b). Here we use the data averaged over $4 \mathrm{~s}$, resulting in a ver- tical resolution of $20 \mathrm{~m}$ during ascent and $50 \mathrm{~m}$ during the parachuted descent in the lower stratosphere. The detection limit is 0.1 ppmv. The flight configuration of FLASH-B, in which the analysed volume is located beneath the downwardlooking optics, causes self-contamination due to water outgassing from the instrument and eddy diffusion above about $70 \mathrm{hPa}$ during ascent when the contribution of water residing on the instrument walls becomes comparable to the ambient vapour pressure. By contrast, the descent measurements at the bottom of the flight train in undisturbed air are contamination-free throughout the stratosphere (Khaykin et al., 2013b).

Pico-SDLA $\mathrm{H}_{2} \mathrm{O}$ and $\mathrm{CH}_{4}$ are lightweight infrared spectrometers measuring in situ water vapour at $2.63 \mu \mathrm{m}$ and methane at $3.24 \mu \mathrm{m}$ respectively by direct absorption spectroscopy (Durry et al., 2008; Ghysels et al., 2011). The optical path length for water vapour and methane measurements are 1 and $3.6 \mathrm{~m}$ respectively in ambient air. During the campaign the mass of these spectrometers with the electronic parts and the mechanical protections was less than $9 \mathrm{~kg}$ (Pico-SDLA $\mathrm{H}_{2} \mathrm{O}$ ) and around $15 \mathrm{~kg}\left(\mathrm{Pico}_{-} \mathrm{SDLA} \mathrm{CH}_{4}\right)$. The uncertainty of the measurements is defined by the signal-tonoise ratio of the spectra, the polynomial order for baseline fitting, the number of points chosen for the interpolation, the quality of the spectroscopic parameters and the temperature and pressure measurement accuracy. The total uncertainty of water vapour measurements ranges from 7.5 to $3.5 \%$ in the TTL. The total uncertainty of methane measurements ranges from 3.5 to $5 \%$ between 15 and $22 \mathrm{~km}$ (Ghysels et al., 2014).

Compact Optical Backscatter Aerosol Detector (COBALD) is a compact balloon-borne backscatter instrument developed in the group led by Prof. Thomas Peter at ETH Zurich. With a total weight of approximately $550 \mathrm{~g}$ including batteries, COBALD measures molecular, aerosol and cloud particle backscatter in the atmosphere from the ground to the level of balloon burst. COBALD sondes have been applied for studies of cirrus clouds (Brabec et al., 2012; Cirisan et al., 2014) volcanic aerosol (Bukowiecki et al., 2011) and non-volcanic aerosol (Vernier et al., 2015). The instrument makes use of two LEDs of $250 \mathrm{~mW}$ optical power each emitting light at 455 and $940 \mathrm{~nm}$ wavelengths. To register the backscattered light, a silicone photodiode is placed between the LEDs, and the associated optics establishes an overlap region at distances larger than $0.5 \mathrm{~m}$ in front of the instrument. The instrument is designed for night-time use only, as solar radiation saturates the detector. Radiosonde pressure and temperature are used to calculate the molecular backscatter, which is then used to infer the scattering ratio (SR) as total signal referenced to molecular contribution. The SR profiles are binned to $1 \mathrm{hPa}$ pressure intervals to reduce measurement noise, which typically increases in the stratosphere. While the SR is not quantified absolutely, the analysis of the entire sounding profile leads to an absolute error interval of $5 \%$ with precision better than $1 \%$ in the lower stratosphere (Vernier et al., 2015). 
By definition, the aerosol contribution to the SR (aerosol scattering ratio) is given as a surplus with respect to unity, i.e. $\mathrm{SR}-1$.

\subsection{Remote sensing instruments}

An S-band weather radar of IPMet was continuously operating at the campaign site and provided information on the echo top heights. The IPMet radar has a $2^{\circ}$ beam width and a range of $450 \mathrm{~km}$ for surveillance, but when operated in volume scan mode every $7.5 \mathrm{~min}$, it is limited to $240 \mathrm{~km}$, with a radial resolution of $250 \mathrm{~m}$ and $1^{\circ}$ in azimuth, recording reflectivities, spectral width and radial velocities at 16 elevations between 0.3 and $45^{\circ}$.

The Microwave Limb Sounder (MLS) instrument, launched in 2004 on board the Aura satellite, is designed to measure a number of chemical species and temperature and provides over 3500 vertical profiles per day evenly distributed between $82^{\circ} \mathrm{S}$ to $82^{\circ} \mathrm{N}$. Here we use the version 4.2 water vapour profiles described by Livesey et al. (2015) who report, for the lower to middle stratosphere, a vertical resolution of $2.8-3.2 \mathrm{~km}$, a horizontal resolution of $198-290 \mathrm{~km}$, an accuracy of 4-9\% and a precision of $6-15 \%$. The data screening criteria specified by Livesey et al. (2015) have been applied to the data.

Cloud-Aerosol Lidar with Orthogonal Polarization (CALIOP) is a primary instrument on board the CALIPSO satellite, in operation since 2006 (Winker et al., 2009) and providing backscatter coefficients at 532 and $1064 \mathrm{~nm}$. The vertical resolution of CALIOP varies with altitude, from $30 \mathrm{~m}$ in the lower troposphere to $180 \mathrm{~m}$ in the stratosphere. In this study we use the CALIOP night-time $532 \mathrm{~nm}$ level 1B version 4.0 product for computing zonal-mean scattering ratios after discarding the South Atlantic magnetic anomaly zone. The data are post-processed using a treatment described by Vernier et al. (2009) and cloud-cleared in the upper troposphere using a depolarisation ratio threshold of $5 \%$.

\subsection{Trajectory and transport modelling}

For tracking the origin of air masses sampled in situ by the balloons, we use the models HYSPLIT and CLaMS. HYSPLIT (Hybrid Single-Particle Lagrangian Integrated Trajectory) model (Stein et al., 2015) was fed by GDAS (Global Data Assimilation System) reanalysis provided at $0.5^{\circ} \times 0.5^{\circ}$ grid and $55 \sigma$-pressure levels between the surface and $10 \mathrm{hPa}$. The trajectories are calculated using altitude as the vertical coordinate, with the vertical velocity deduced from the GDAS meteorological fields. CLaMS (Chemical Lagrangian Model of the Stratosphere) is a modular Chemistry Transport Model (CTM) developed at Forschungszentrum Jülich, Germany (McKenna et al., 2002). The model transport is driven by the meteorological fields from the European Centre for Medium-range Weather Forecasts (ECMWF) ERA-Interim reanalysis (Dee et al., 2011). The trajectories are calculated using potential temperature as the vertical coordinate, with the (diabatic) vertical velocity deduced from the forecast total diabatic heating rate (Andrews et al., 1987, Eq. 3.1.3e). Small-scale atmospheric mixing is parameterised in the Lagrangian model CLaMS in relation to shear and strain rates in the large-scale flow, such that the mixing occurs in regions of strong flow deformations. Further details about CLaMS simulation used here are given by Pommrich et al. (2014).

\section{Evidence of horizontal transport (in-mixing)}

\subsection{Detection of in-mixing signatures}

Five balloon measurements of water vapour (FLASH-B and Pico-SDLA) and aerosol (COBALD) conducted over a period between 11 and 16 March 2012 revealed a recurring $300-500 \mathrm{~m}$-thick layer of enhanced water vapour and aerosol concentration centred at the $425 \mathrm{~K}$ potential temperature level $(\sim 18.5 \mathrm{~km})$. The amplitude of enhancements reached $15 \%(0.5 \mathrm{ppmv})$ in water vapour mixing ratio and $29 \%$ in aerosol scattering ratio. A methane vertical profile obtained by the Pico-SDLA instrument on 14 March revealed a reduction of $\mathrm{CH}_{4}$ mixing ratio by $100 \mathrm{ppbv}(\sim-6 \%)$ at the same level. Figure 1 displays the vertical profiles of water vapour (solid red) and scattering ratio (solid green) obtained on 13 March, when the layer had the largest thickness and amplitude of enhancement. The methane profile (solid blue) obtained on 14 March, featuring a local minimum in the corresponding layer, is also displayed in Fig. 1. Note that the altitude and amplitude of the water vapour enhancement are identical to those reported by the Pico-SDLA hygrometer (see Sect. 2 and Ghysels et al., 2016). Two other local maxima in water vapour, detected by FLASH-B at 404 and $386 \mathrm{~K}$, do not have corresponding enhancements in SR and are not observed in other flights. These features are discussed in Sect. 4. The nearest matching MLS water vapour profile (red/black squares), acquired on the same night, $\sim 50 \mathrm{~km}$ away from the sounding location, is also provided in Fig. 1. It demonstrates a good agreement with the coincident balloon measurements, although the subkilometre vertical structures are expectedly missed by MLS.

COBALD backscatter measurements were converted to $532 \mathrm{~nm}$ for comparison with CALIPSO after deduction of the Angstrom exponent from 455 and $940 \mathrm{~nm}$ COBALD channels, similarly to Vernier et al. (2015). The zonally and monthly averaged SR profile from CALIPSO (green/black circles), showing a step-like increase in scattering ratio just above the upper boundary of TTL, is consistent with COBALD profile; however the enhancement at $425 \mathrm{~K}$ is only seen in COBALD local observation. This suggests a limited spatio-temporal extent of the observed feature. 


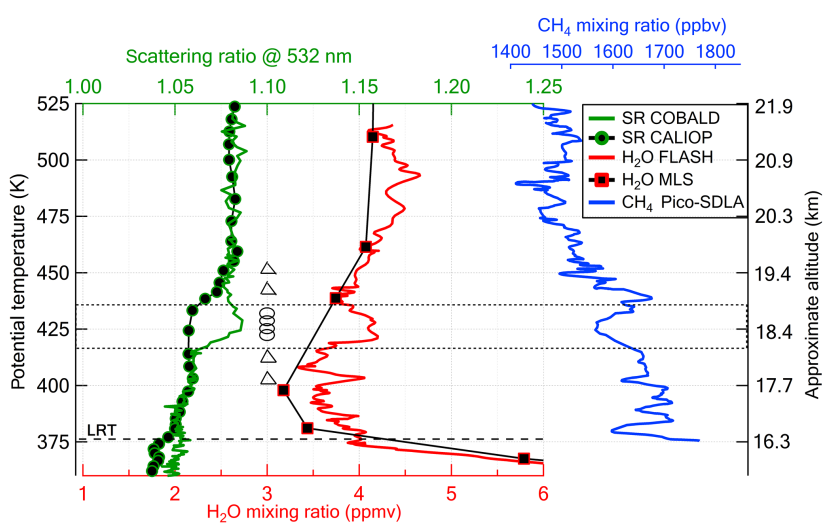

Figure 1. Vertical profiles of scattering ratio from COBALD (solid green, 13 March) and CALIPSO (green/black circles, February zonal mean), water vapour from FLASH-B (solid red, 13 March) and MLS (red/black squares, 13 March), methane (solid blue, PicoSDLA on 14 March). Horizontal dotted lines mark the lower and upper boundaries of the water/aerosol-enriched and methane-depleted layer. Horizontal dashed line marks the lapse rate tropopause (LRT) level. The circles and triangles indicate the altitude levels, from where CLaMS back trajectories were initialised (same convention for the markers is used in Fig. 2). See text for detail.

\subsection{Satellite perspective and trajectory modelling}

The origin of the observed layer is investigated using CLaMS trajectories initialised at eight levels within and around the layer - these levels are marked by circles and triangles in Fig. 1. The same convention for markers is used in Fig. 2, displaying the latitudinal locations of the air masses from within and outside the layer 15 days prior to the 13 March sounding. Trajectory analysis suggests that the water/aerosol-enriched layer originates from the extratropical stratospheric overworld $(\theta>380 \mathrm{~K})$, as opposed to the layers directly below and above, which are traced back from within the Southern Hemisphere tropics. The transport from middle and high latitudes is of quasi-isentropic nature as the isentropes shown in Fig. 2 suggest.

The latitude-altitude distribution of water vapour from MLS displayed in Fig. 2 explains the enhanced humidity of the layer: the extratropical stratosphere around the $440 \mathrm{~K}$ level contains about $20 \%$ more water than the tropical lower stratosphere. Indeed, the mixing ratio of $4.2 \mathrm{ppmv}$ measured in situ within the layer is fully compatible with MLS zonalmean values at the source locations. The same interpretation is applicable to the enhanced aerosol in situ readings in the layer: higher aerosol load (SR > 1.07) of the southern midlatitude stratosphere is evident.

The water vapour minimum throughout the TTL, as seen by MLS in February, is associated with dehydration of air parcels advected through the "cold trap" predominantly above the western Pacific region (Holton and Gettelman, 2001). The increase of LS water towards high latitudes is
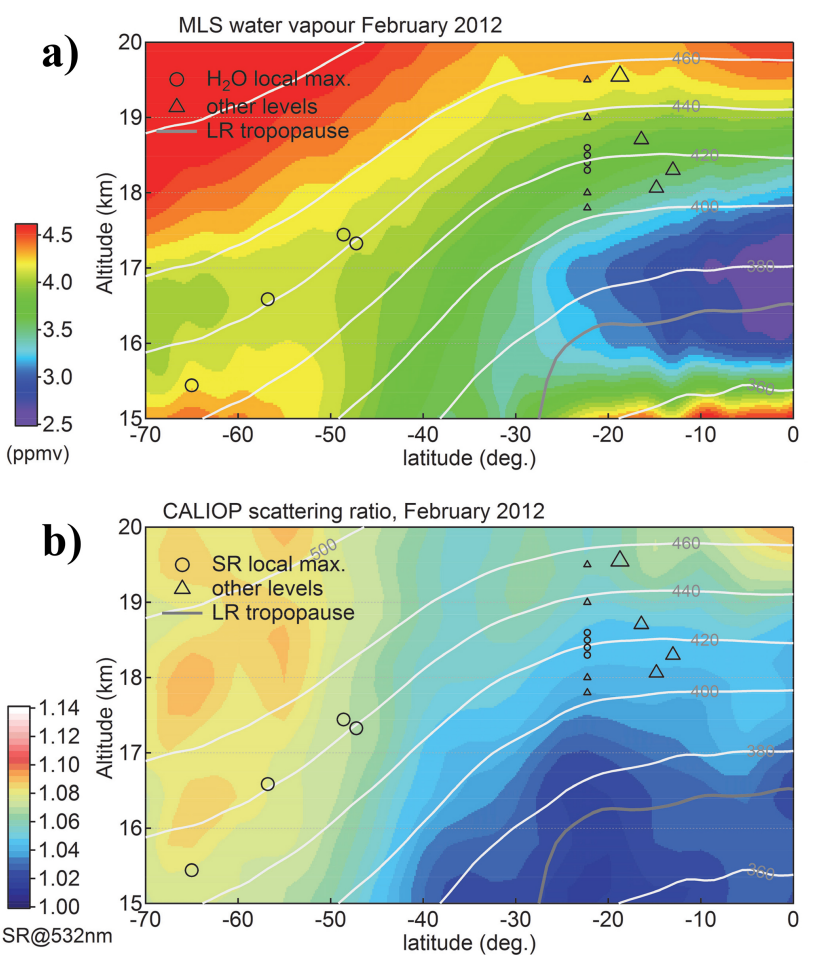

Figure 2. Latitude-altitude section of monthly zonal mean MLS water vapour (a) and CALIPSO scattering ratio (b). Larger markers (circles and triangles) indicate the location of the sampled air masses 15 days prior to balloon sounding on 13 March (same convention as in Fig. 1) Smaller markers indicate the locations where trajectories were initialised. Circles denote the trajectories initialised from the WV/SR enhancement; triangles denote trajectories initialised at levels below and above. The isentropes (white contours) and the lapse rate (LR) tropopause (grey curve) were calculated using zonally averaged COSMIC GPS radio-occultation measurements (Anthes et al., 2008).

commonly associated with the diabatic subsidence of air enriched with water through methane oxidation - in the descending branch of Brewer-Dobson circulation. For this reason the extratropical stratosphere contains more water vapour and less methane. The latitude distribution of aerosol load, featuring a minimum in the TTL and midlatitude lowermost stratosphere, can be explained by cross-tropopause transport of clean tropospheric air (cleansing) during the austral summer convective season (Vernier et al., 2011).

\subsection{CLaMS transport simulation}

The in-mixing of extratropical air - as suggested by the trajectory analysis - is precisely demonstrated by the water vapour fields simulated by CLaMS. Figure 3 a displays the CLaMS water vapour at $420 \mathrm{~K}$ above South America and South Atlantic ocean. The simulation reports water mixing ratios below 3 ppmv wherever the winds are easterly, that is mainly within the tropical belt, where water vapour is de- 
(a)

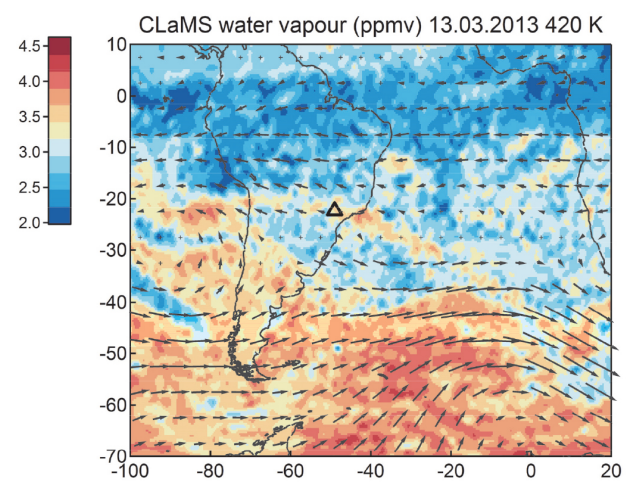

(b)

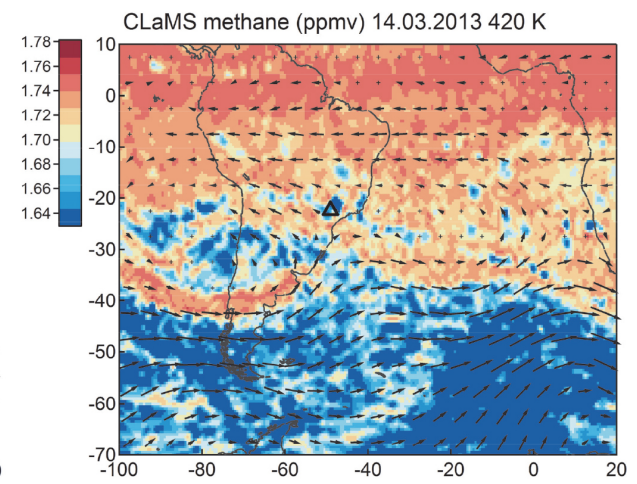

Figure 3. CLaMS simulated fields of water vapour for 13 March (a) and methane for 14 March (b) with ERA-Interim winds superimposed. A filament of water-rich and methane-poor air extending above the sounding location (marked by the triangle) is clearly visible.

pleted by "cold trap" dehydration. South of $40^{\circ} \mathrm{S}$, strong westerly winds and higher mixing ratios ( $>4 \mathrm{ppmv}$ ) prevail. The ERA-Interim wind fields in Fig. 3 show an enhanced meridional wind component above the South Atlantic, related to a Rossby wave breaking event (as suggested by ERAInterim potential vorticity fields, not shown), which supplies humid high-latitude air up to $40^{\circ} \mathrm{S}$, where it is entrained by the tropical zonal flow. As a result, a moist filament, several thousand kilometres long and only a few hundred kilometres thick, is formed. The filament extends sharply above the sounding location on 13 March.

Over the following days, as suggested by the model simulations (not shown), the filament weakens, mixes out with the ambient drier air and vanishes completely by 17 March. According to CLaMS, the intrusion was most prominent on 13 March, which is fully compatible with the balloon soundings that showed a maximum amplitude of water enhancement at $420-430 \mathrm{~K}$ on 13 March. Simulation of methane fields (Fig. 3b) at this level reveals a corresponding filament of methane-poor air, which is compatible with the in situ methane profile of 14 March, showing a subtle reduction of methane mixing ratio at the $425 \mathrm{~K}$ level. A notable anticorrelation between the water and methane fields is expectable since photochemical oxidation of methane in the stratosphere yields water vapour. The age of air inside the filament - as estimated using CLaMS - is 18 months on average, which is substantially older than the tropical belt air, with mean age of about 7-8 months.

\section{Evidence of vertical transport of water (overshooting)}

In the previous section we showed that the enhancements in water vapour and aerosol at $425 \pm 5 \mathrm{~K}$, detected in a series of successive soundings and corresponding to methane reduction feature, can be unambiguously attributed to long-range horizontal transport (in-mixing). However, this interpretation does not hold for the two other water vapour enhancements at 404 and $386 \mathrm{~K}$ - specific to a single sounding, which prompts us to seek for another origin of these features.

\subsection{Hydration signatures}

Figure 4 displays water vapour and temperature profiles obtained by Pico-SDLA (balloon descent) and FLASH$\mathrm{B}$ (ascent and descent) successively in time in the quasisimultaneous soundings of 13 March. The levels of interest, at which the FLASH-B descent profile showed sharp enhancements, are marked by dashed lines with an indication of time when these levels were sampled. The FLASH-B ascent profile is limited to below $18.7 \mathrm{~km}$ as the measurements above that level are affected by water outgassing, which introduces a positive bias (with respect to the clean descent measurement) increasing with altitude (Sect. 2.1).

The Pico-SDLA descent profile (Fig. 4a) shows a $240 \mathrm{~m}$ thick humid layer centred at $404 \mathrm{~K}(17.8 \mathrm{~km}, 82 \mathrm{hPa}$, 22:06 UTC) with an amplitude of enhancement of $0.6 \mathrm{ppmv}$. The amplitude is estimated as a difference between the peak value of the enhancement and a mean value over the underlying and overlying $300 \mathrm{~m}$-thick layers. In the ascent profile of FLASH-B (Fig. 4b), the enhancement at $404 \mathrm{~K}$ is discernible; however its amplitude $(\sim 0.2 \mathrm{ppmv})$ is close to the detection limit of the instrument $(0.1 \mathrm{ppmv})$. The descent profile of FLASH-B (Fig. 4c) reveals two sharp enhancements, both around $200 \mathrm{~m}$-thick: at $404 \mathrm{~K}(0.5 \mathrm{ppmv})$ and a smaller one $(0.4 \mathrm{ppmv})$ at $386 \mathrm{~K}(17.1 \mathrm{~km}, 93 \mathrm{hPa}$, 23:46 UTC). The lower layer has a lower amplitude of enhancement $(0.2 \mathrm{ppmv})$ in the FLASH-B ascent profile and is barely discernible in the Pico-SDLA descent profile. Note that given the balloon flight trajectories, the horizontal distance between the detections of humid layers by Pico-SDLA and FLASH-B does not exceed $30 \mathrm{~km}$ and $100 \mathrm{~min}$, whereas FLASH-B ascent and descent measurements at $17-18 \mathrm{~km}$ altitude are only $10 \mathrm{~km}$ and $30 \mathrm{~min}$ apart. 

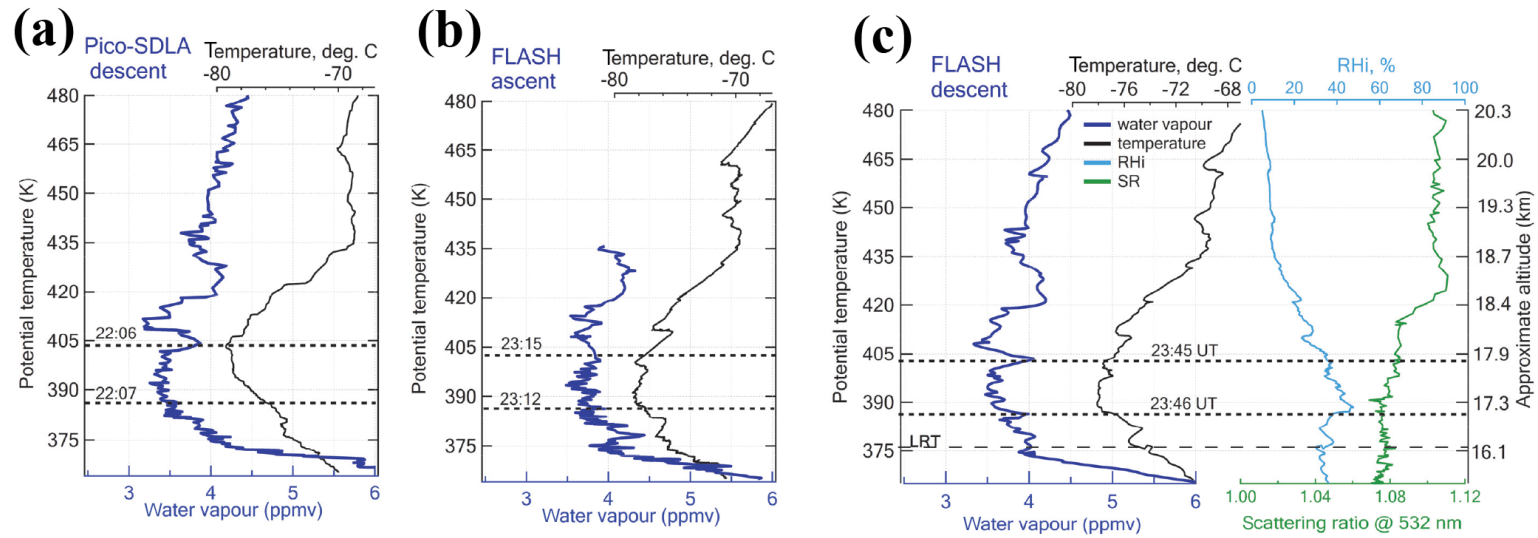

Figure 4. Water vapour (blue) and temperature (black) vertical profiles obtained successively in time on 13 March by (a) Pico-SDLA on descent, (b) FLASH-B on ascent (outgassing-biased part removed), (c) FLASH-B on descent. The cyan and green curves in the right-hand panel indicate relative humidity with respect to ice (RHi, top axis, FLASH/RS92) and scattering ratio at $532 \mathrm{~nm}$ (SR, bottom axis, COBALD). The horizontal dashed lines mark the levels where hydrated layers in (c) were sampled with indication of the sampling time (UTC). The thin dashed line indicates the level of lapse rate tropopause (LRT, 376 K).

Notable variability of water vapour vertical structure on a scale of a few tens of kilometres (minutes) indicates local processes such as overshooting convection, capable of injecting water above the tropopause. Throughout the paper we refer to the term "overshooting" with regard to the mass transport across the lapse rate tropopause (LRT). The LRT altitude on 13 March inferred from the FLASH-B sounding (RS92) amounted to $16.4 \mathrm{~km}$.

\subsection{Convective activity on 13 March}

An extremely weak pressure gradient over south-eastern Brazil, combined with the equally weak upper air circulation, provided an ideal situation for convective activity over the State of São Paulo on 13 March. Isolated thunderstorms first developed in the south-east sector of the IPMet radar around noon, local time (UTC $-3 \mathrm{~h}$ ), but quickly consolidated into large multicellular complexes, with several cells overshooting into the lower stratosphere during the later afternoon. A sequence of radar echo top images $(240 \mathrm{~km}$ range, reflectivity threshold 10 dBZ) between 10:00 and 15:00 UTC, acquired every $7.5 \mathrm{~min}$, revealed over 10 different convective cells reaching above $17 \mathrm{~km}$.

Shown in Fig. 5 is a composite radar image including all echo tops reaching above $15-17 \mathrm{~km}$ (see Sect. 4.4 for interpretation of the echo top altitudes) detected by the radar on 13 March in the upwind quadrant of the soundings. Whereas the convective cloud systems hosting the overshooting cells extended for over $100 \mathrm{~km}$, the areas of radar echoes above $17 \mathrm{~km}$ were limited to a few tens of kilometres or less in diameter. The lifetime of overshooting cells, emerging sporadically above the "mother cloud", was typically limited to two successive radar volume scans, i.e. 15-29 min.

Given the position of the overshooting cells relative to the balloon soundings and the weak wind velocity in the TTL

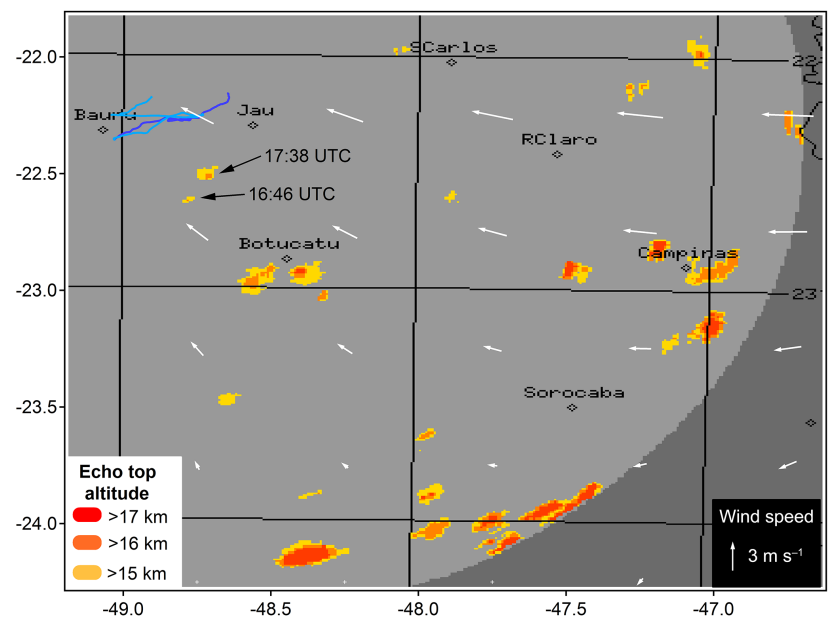

Figure 5. Composite radar image of all convective cells reaching above $15 \mathrm{~km}$ detected on 13 March by IPMet radar in the upwind quadrant of Bauru. Black arrows tag the overshooting cells potentially responsible for the hydrated layers shown in Fig. 4 with indication of the UTC of their detection by radar. White arrows represent the mean wind field between 100 and $70 \mathrm{hPa}$ from ERA-Interim reanalysis (18:00 UTC). Blue lines indicate the balloon trajectories (FLASH-B dark blue, Pico-SDLA light blue).

$\left(<5 \mathrm{~m} \mathrm{~s}^{-1}\right)$, one can assume that the cells closest to Bauru (e.g. those tagged by black arrows in Fig. 5) are more likely to affect the composition of air sampled by the balloons.

Figure 6 displays the temporally resolved cumulative area of all overshooting cloud tops observed on 13 March within the quantitative detection range of the IPMet radar $(240 \mathrm{~km})$. The peak of the overshooting area around 17:00 local time, which is consistent with a typical diurnal cycle of convection above land (Liu and Zipser, 2005), is remarkable. The max- 


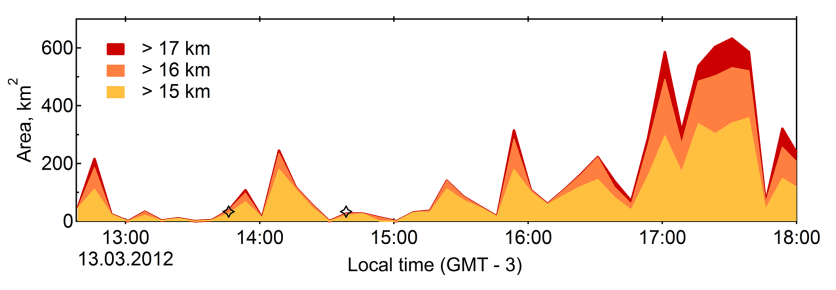

Figure 6. Temporal evolution of cumulative overshooting area at different levels of TTL recorded by IPMet radar on 13 March within its $240 \mathrm{~km}$ range $(10 \mathrm{dBZ}$ reflectivity threshold). The black stars mark the timing of overshooting cells shown in Figs. 5 and 7.

imum convective activity was recorded at 17:30 local time (14:30 UTC), when the total area of cloud tops above 17 and $16 \mathrm{~km}$ reached 100 and $200 \mathrm{~km}^{2}$ respectively. For comparison, the combined overshooting area of the two small cells closest to Bauru (marked by arrows in Fig. 5 and by stars in Fig. 6) constitutes only about $4 \%$ of the daily maximum of total cloud area above $16 \mathrm{~km}$.

\subsection{Overshoot tracking}

The overshooting cells potentially responsible for the water enhancements were identified using HYSPLIT backward trajectories (not shown) and a sequence of radar echo top images. The hydrated air parcels sampled at 404 and $386 \mathrm{~K}$ were traced backward in time, through the radar scans sequence, until a parcel's trajectory matched in space and time with a convective cell reaching above $16 \mathrm{~km}$. Two different convective cells, Cell 1 occurring at 16:46 UTC and Cell 2 at 17:38 UTC (marked by black arrows in Fig. 5) with overshooting tops located at 45 and $32 \mathrm{~km}$ respectively upwind from the FLASH-B sampling location (49 and $37 \mathrm{~km}$ from Pico-SDLA), were identified for both hydrated layers. It should be noted that the trajectory calculations strongly depend on the accuracy of the wind fields in the meteorological data fed into the model. This becomes particularly important when the tracked target (overshooting cell in this case) is smaller than a grid cell of meteorological data field. We attempt to compensate for this uncertainty by computing an ensemble of trajectories to estimate the dispersion of air parcels affected by overshooting convection.

Figure 7 shows two blow-ups of the radar echo top images, where the overshooting cells, presumably responsible for the hydrated layers, are outlined with black rectangles. Superimposed on each radar image is an ensemble of 144 forward trajectories initialised within the rectangles at four levels corresponding to the vertical extent of the hydrated layers and spaced vertically by $50 \mathrm{~m}$. The trajectory ensembles, colour-coded by UTC, show the spatio-temporal evolution of the plumes of overshooting cells. Note that the altitude excursions of the air parcels did not exceed $200 \mathrm{~m}$ according to HYSPLIT simulations. The locations where the hydrated layers were sampled are marked with circles along FLASH$\mathrm{B}$ and Pico-SDLA balloon flight trajectories.

Cell 2, linked at $404 \mathrm{~K}$ to the hydrated layer by trajectories (Fig. 7b) had a lifetime of two radar scans and a diameter of less than $10 \mathrm{~km}$. Its plume, as suggested by the trajectory ensemble, reached the sounding locations by 22:00 UTC and covered all three sampling locations where the hydrated layers were detected. The FLASH-B ascent sampling at 23:15 UTC is located on the edge of the plume, which may explain the subtlety of the corresponding water vapour enhancement (Fig. 4b). Cell 1, linked with the hydrated layer at $386 \mathrm{~K}$ (Fig. 7a), had yet smaller size and a lifetime limited to a single radar scan. Its plume had a smaller dispersion and covered the FLASH-B sampling locations only, which is likely why the hydrated layer at $386 \mathrm{~K}$ was not unambiguously detected by Pico-SDLA (Fig. 4a).

Overall, the above analysis suggests a relation between the hydrated layers and convective overshoots upwind, which occurs 5-6h before the soundings. The question is - could any other overshooting cells in the upwind area be responsible for the hydrated layers? As can be seen in Fig. 5, the overshooting cells at 16:46 and 17:38 UTC are remarkably smaller than the other ones occurring upwind on that day; however the ERA-Interim wind velocities in the 100-70 hPa layer (shown as white vectors in Fig. 5) of the order of $5 \mathrm{~m} \mathrm{~s}^{-1}$ or less would not allow more distant overshoots to be transported in time to the sounding location. For example, the plumes of two larger cells detected south of Botucatu (Fig. 5) would have reached the sounding locations several hours after the measurements were taken. On the previous day (12 March) a medium-sized overshooting cell was detected about $200 \mathrm{~km}$ south-east of Bauru at 14:16 UTC (not shown); however its location and timing do not allow us to link it with the sounding location using trajectories. Therefore we are led to conclude that the two small overshooting cells of 13 March closest to the measurement location are the most likely sources of the hydrated layers. That said, we cannot entirely rule out the contribution from other convective cells because faster subgrid-scale winds, unresolved by the reanalysis, may exist around the strong convection.

\subsection{Overshooting top altitude}

The two overshooting cells shown in Fig. 7 are characterised by extremely strong updrafts, facilitating their rapid vertical growth. Figure 8 shows Cell 1 and Cell 2 vertical crosssections, highlighting the complexity of the cell structure and airflow. The vertical cuts were made along the base lines A-B and $\mathrm{C}-\mathrm{D}$ (shown in Fig. 7a and b) using a reflectivity threshold of $-6 \mathrm{dBZ}$ (cf. $10 \mathrm{dBZ}$ in Figs. 5 and 7) to enhance the sensitivity in the near range (the $-2 \mathrm{dBZ}$ contour is visible up to a range of $40 \mathrm{~km}$ ). The maximum reflectivity was 52.8 and $54.2 \mathrm{dBZ}$ in Cell 1 and Cell 2 respectively, typical for severe tropical storms, likely to produce hail on the ground. 

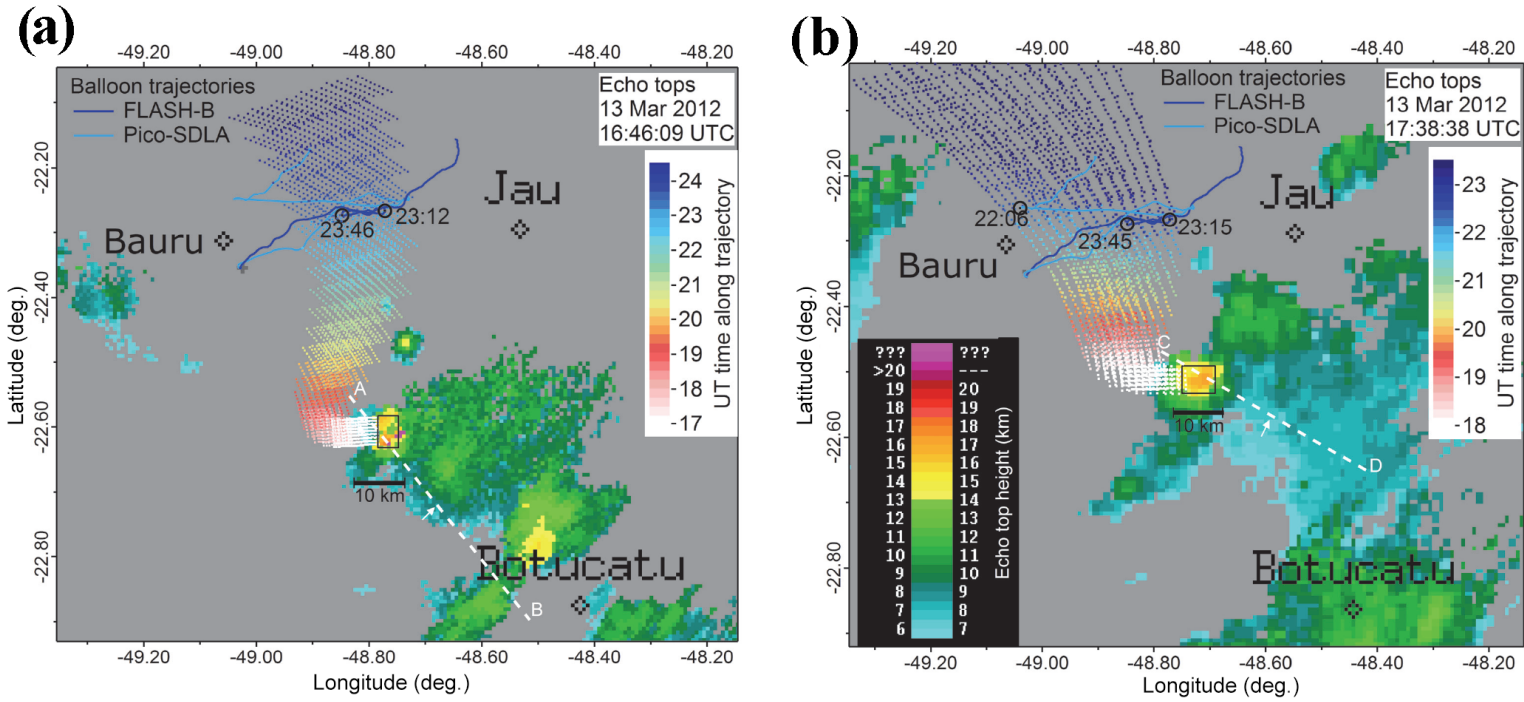

Figure 7. Echo top maps (reflectivity threshold $10 \mathrm{dBZ}$ ) recorded by IPMet radar on 13 March. The overshooting cells, linked by trajectories with hydrated layers at 386 and $404 \mathrm{~K}$ are outlined by rectangles in (a, b). Solid lines indicate the trajectories of balloons carrying FLASH-B and Pico-SDLA hygrometers with indication of time (UTC) when 386 and $404 \mathrm{~K}$ levels were sampled. Dots depict the ensembles of forward trajectories (colour-coded by UTC) initialised within the rectangle. Dashed white lines A-B in (a) and C-D (b) show the bases of vertical cross-section of the convective cells provided in Fig. 8.

(a)

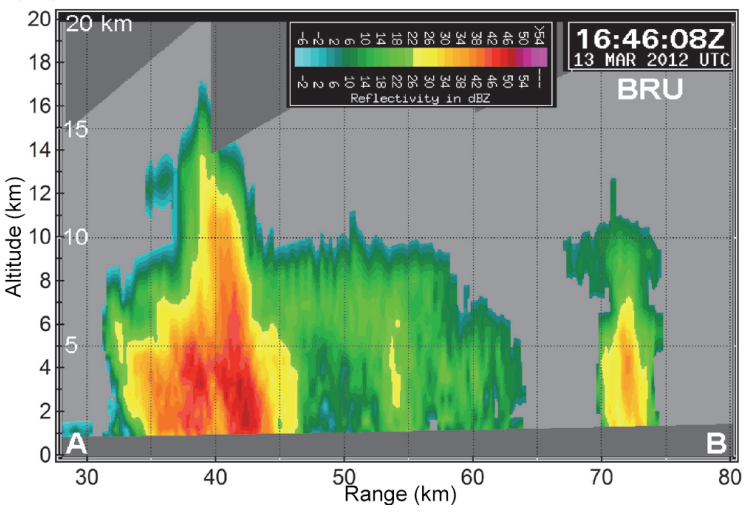

(b)

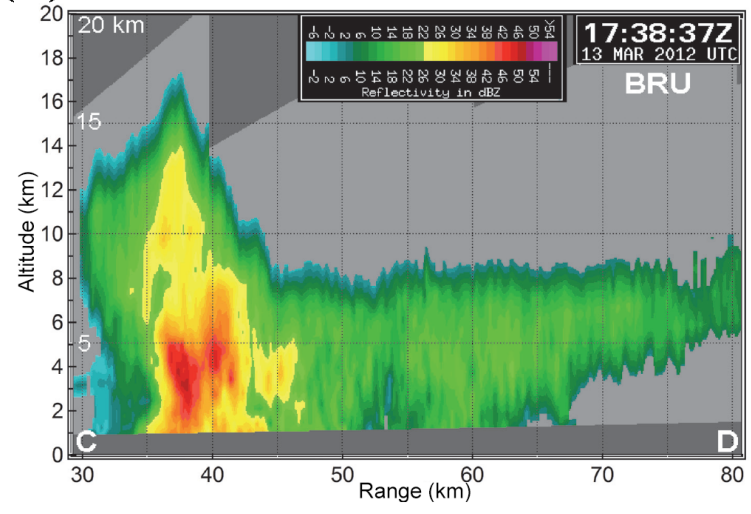

Figure 8. Vertical cross section of IPMet radar reflectivity on 13 March of (a) Cell 1 (16:46 UTC, baseline A-B in Fig. 7a), (b) Cell 2 (17:38 UTC, baseline C-D in Fig. 7b). Dark grey shading in the top of the plots corresponds to the areas without radar PPI overlapping coverage.

The maximum height of the radar echo top for cells 1 and 2 was 17.1 and $17.3 \mathrm{~km}$ respectively as can be inferred from Fig. 8. While this is consistent with the altitude of the corresponding moist layers, it is important to point out that radar can only detect raindrops, whereas the actual top of the cloud is likely to extend significantly higher, where ice crystals are the only hydrometeors in the overshooting turret, but which cannot be detected by the S-band radar.

The radial velocity cross-sections for both cells (not shown) obtained from the IPMet Doppler radar suggest that the outflow from both cells into their anvils exceeded $-13 \mathrm{~m} \mathrm{~s}^{-1}$ (negative radial velocities indicate that the radial component of the three-dimensional movement of raindrops is towards the radar). Considering the ambient flow field of about $3 \mathrm{~m} \mathrm{~s}^{-1}$ in the same direction (Fig. 5), the true outflow velocity can be estimated at about $10 \mathrm{~m} \mathrm{~s}^{-1}$. The Cell 1 translation was only $2.7-4 \mathrm{~m} \mathrm{~s}^{-1}$ towards the north-east, but would contribute to redirect the moisture flux towards the balloon trajectories. Similar results are obtained for Cell 2.

\subsection{Hydration process}

The overshooting hydration is commonly conceived as a twostage process: a geyser-like injection of adiabatically cooled 
air (Danielsen, 1993; Jensen et al., 2007) together with ice particles (Nielsen et al., 2007; Corti et al., 2008) that further sediment out and/or sublimate, thereby locally increasing the water vapour amount at the level of detrainment (Khaykin et al., 2009; Schiller et al., 2009). Small cooling features $(\sim-1 \mathrm{~K})$ corresponding to the hydrated layer at $404 \mathrm{~K}$ are discernible in Fig. 4; however the backscatter measurements during that flight (green curve in Fig. 4c) do not provide any indication for the presence of ice particles in the hydrated layers. Apparently, the ice detrained from convective updrafts has fully sublimated (or partly precipitated) before the plume was sampled. Indeed, the minimum saturation mixing ratio in the TTL - as derived from radiosonde data from the FLASH-B flight - amounted to $8.5 \mathrm{ppmv}$ at $404 \mathrm{~K}$ (which translates into $47 \%$ relative humidity over ice $-\mathrm{RHi}$, cyan curve in Fig. 4c), implying that the air was far from saturation conditions.

It should be kept in mind that subsaturation of air at and above the level of detrainment is a prerequisite for hydration of the stratosphere through overshooting. If the TTL above the level of detrainment is close to saturation, the stratospheric hydration is possible only if the humid air is injected above the temperature minimum (CPT), otherwise any amount of additional water in excess of the minimum saturation would freeze out as it rises into the stratosphere. Furthermore, if TTL is initially supersaturated, an overshoot can lead to dehydration as the excess vapour condenses on the ice crystals (Jensen et al., 2007). In a generalized case, an overshoot must surpass the CPT level to ultimately hydrate the stratosphere; however if CPT is well below the saturation - as is the case here - any overshoot above the level of zero radiative heating (LZRH, $\sim 360 \mathrm{~K}$, Fuegustaler et al., 2009) can potentially hydrate the stratosphere. In the case of 13 March, sounding CPT is found at $387 \mathrm{~K}(17.3 \mathrm{~km})$, which is slightly above the lower humid layer $(386 \mathrm{~K})$ but well below the upper humid layer (404 K).

The observation of overshooting hydration presented here can be compared to a similar case captured by a balloon sounding conducted during monsoon season in western Africa (Khaykin et al., 2009). However, in that case, a water vapour enhancement of $1.1 \mathrm{ppmv}$ was observed together with a layer of ice particles in subsaturated air (56\% RHi) above a cloud anvil at $392 \mathrm{~K}$ (17.6 km altitude), indicating the ongoing sublimation of ice. A small cooling signature and a dip in ozone within the moist layer were also observed. The analysis of local radar acquisitions in Africa suggested that the ice was injected by a nearby upwind overshooting cell, 3060 min before the detection - a much shorter time interval than that $(5-6 \mathrm{~h})$ in the present case.

\section{Discussion and summary}

High-resolution balloon-borne measurements of water vapour and aerosol reported here provide insights into the processes controlling the composition and structure of the TTL. The credibility of water vapour measurements exploited is confirmed by the excellent agreement between FLASH-B and Pico-SDLA hygrometers (Ghysels et al., 2016), capturing identical vertical structures. The analysis provided above links the observed fine structures of TTL water vapour with two independent and concurrent transport processes - in-mixing from the extratropical stratosphere and convective hydration - both reflected by local enhancements of water vapour mixing ratio of similar amplitude. Remarkably, the signatures of both transport pathways, vertically spaced by only a few hundreds of metres, were coexisting in the same balloon profile.

The interpretation of the observed structures and their attribution to different transport pathways into the TTL was based on the use of satellite and ground-based radar observations together with back trajectories and transport modelling. CLaMS simulation precisely reproduces the signature of in-mixing from the extratropical LS, reflected in the measurements as coincident water vapour enhancement and methane depletion at $420-430 \mathrm{~K}$. Both vertical and temporal extents of the observed features are fully consistent with those suggested by CLaMS simulation, revealing an intrusion of water-rich and methane-poor air within an elongated filament. The coincident local maximum of scattering ratio was interpreted using CALIPSO observations, showing larger aerosol load in the extratropical LS compared to the clean TTL. Although coincident enhancements in water vapour and aerosol can be in principle interpreted as a result of convective injection of ice particles and their partial sublimation, the argumentation provided above strongly supports the idea of horizontal in-mixing as being the cause.

The effect of in-mixing on the TTL composition and its seasonality is known to be most apparent in tracers of stratospheric origin and with strong meridional gradients in the lower stratosphere (Ploeger et al., 2012). Indeed, in-mixing was found to contribute considerably to the annual cycle of ozone above the tropical tropopause (Konopka et al., 2009, 2010). At the same time, the effect of in-mixing on the TTL water vapour seasonality is expected to be small at the tropics-wide scale (Ploeger et al., 2012). The in situ evidence of water vapour enhancement of $15 \%$ in a 500 m-thick layer due to in-mixing - as reported in this study - can neither dispute nor support the above inference. Hence, we can only conclude that the intrusion of midlatitude air (containing slightly more water and slightly less methane) into the uppermost TTL predicted by CLaMS is fully confirmed by the measurements provided here. We note also that the manifestation of this transport pathway in water vapour and methane has never been previously evidenced by observations.

A less expected phenomenon evidenced by our observations is the effect of in-mixing on aerosol content of the TTL in the absence of volcanic eruptions injecting sulfur into the stratosphere. While a local maximum of aerosol SR at lower stratospheric levels is a typical signature of volcanic plume, 
in our case it is conditioned by a higher stratospheric background aerosol load at midlatitudes with respect to the clean TTL in March, that is after the austral summer convective season, when systematic injections of clean tropospheric air reduce the aerosol abundance throughout the TTL (Vernier et al., 2011).

The fast cross-tropopause transport of clean air by overshooting has been shown to have a global-scale effect on the stratospheric aerosol budget (Vernier et al., 2011). Regional effects of overshooting have been detected in various tropospheric tracers, such as $\mathrm{N}_{2} \mathrm{O}, \mathrm{CH}_{4}$ and $\mathrm{CO}$ (Ricaud et al., 2007, 2009). Carminati et al. (2014) used MLS daytime and night-time observations to investigate the diurnal cycle of water vapour, cloud ice-water and temperature. They found a daytime moistening of the TTL and LS (up to 6\%) over southern tropical land during austral summer, which was attributed to convective hydration. According to Iwasaki et al. (2010), the total number of overshoots penetrating the $380 \mathrm{~K}$ level across the tropical belt is $7 \times 10^{6}$ per year as inferred from CALIPSO and CloudSat radar observations. A hydration of about $100 \mathrm{t}$ per event was estimated from these data. The frequency of clouds above $390 \mathrm{~K}$ was estimated to be $5-10 \%$ by Massie et al. (2010) using High Resolution Dynamic Limb Sounder (HIRDLS) and CALIPSO observations.

It should be noted that MLS, CALIPSO, CloudSat and HIRDLS, all operating within the A-TRAIN constellation, only sample local times around 01:30 and 13:30, and therefore miss the strong late-afternoon peak of convective activity above tropical continents. Another important factor, hindering observation of convective moistening, is the broad vertical resolution of MLS profiles, which completely miss the hydration signatures, manifesting themselves at subkilometre vertical extent. On the modelling side, CTM simulations (like the one reported here), being capable of capturing fine structures due to horizontal transport, do not reproduce overshooting hydration signatures which originate from isolated convective systems. Presently, the localised deep convection and its impact on TTL composition and temperature can only be reliably simulated using non-hydrostatic cloudresolving models. Extrapolation of these results to regional or global scale remains a great challenge, partly due to the lack of observational constraints (Randel and Jensen, 2013). Indeed, the number of in situ observations of moistening above $390 \mathrm{~K}$ is limited to only a few case studies, all quoted in the introduction. The lack of in situ evidence of moistening could be explained by (i) overall lack of high-quality in situ observations of TTL water vapour; (ii) logistical complexity of field operations in the regions of most vigorous convection (e.g. central Africa, Amazonian region or maritime continent) and (iii) difficulty (or impossibility) of balloon and aircraft operations near convective storms.

In this study we report new in situ evidence of convective hydration up to the $404 \mathrm{~K}$ level, detected as a $200-250 \mathrm{~m}$ thick enhancements of water vapour by up to $0.6 \mathrm{ppmv}$
$(18 \%)$. Such a petty feature can hardly be used to support the importance of convective hydration. However, as we point out above, these tiny enhancements owe their existence to very small convective cells with overshooting area of a few square kilometres only and are remarkably smaller than other overshooting clouds observed on that day. Their cumulative effect on TTL water vapour may be substantial.

Interestingly, in our case the in-mixing from the extratropical stratosphere manifests itself in water vapour in a way very similar to what can be expected from convective hydration: the amplitude of enhancement in water vapour amounts to $\sim 0.5 \mathrm{ppmv}$ for both horizontal and vertical transport signatures. However the moistening effect of in-mixing on the tropical LS is limited by the small meridional gradient of water vapour and can hardly exceed $0.5-0.7 \mathrm{ppmv}$. In contrast to that, the convective hydration of LS, which has a global effect proportional to overshoot frequency and intensity, should be limited only by the temperature at the level of injection. This way, a relatively warm TTL/LS above the continents, hosting the most vigorous convection, provides favourable conditions for the convective hydration of LS.

\section{Data availability}

The following satellite data used in this study are publicly available: CALIPSO, https://eosweb. larc.nasa.gov/project/calipso/calipso_table; MLS, http://mls.jpl.nasa.gov/products/h2o_product.php; COSMIC, http://cdaac-www.cosmic.ucar.edu/cdaac/. The data from the balloon experiments can be obtained by contacting the principal author.

Acknowledgements. This work and the TRO-pico project (http://www.univ-reims.eu/minisite_134/tro-pico/ homepage-presentation-of-the-project, 12171,21885.html) were supported by the French Agence Nationale de la Recherche (ANR) under contract ANR-2010-BLAN-609-01 and H2020 ARISE2 project (ref. 653980, http://arise-project.eu/). We express our sincere gratitude to the personnel of IPMet for providing an infrastructure and manpower, especially for their invaluable help with the balloon operation during the campaign. We also thank three anonymous reviewers for useful remarks that helped to improve the article.

Edited by: E. Jensen

Reviewed by: three anonymous referees

\section{References}

Andrews, D. G., Holton, J. R., and Leovy, C. B.: Middle Atmospheric Dynamics, Academic Press, New-York, 489 pp., 1987.

Anthes, R. A., Bernhardt, P. A., Chen, Y., Cucurull, L., Dymond, K. F., Ector, D., Healy, S. B., Ho, S.-P., Hunt, D. C., Kuo, Y.-H., Liu, H., Manning, K., McCormick, C., Meehan, T. K., Randel, W. J., 
Rocken, C., Schreiner, W. S., Sokolovskiy, S. V., Syndergaard, S., Thompson, D. C., Trenberth, K. E., Wee, T.-K., Yen, N. L., and Zeng, Z.: The COSMIC/FORMOSAT-3 Mission: Early Results, B. Am. Meteorol. Soc., 89, 313-333, doi:10.1175/BAMS89-3-313, 2008.

Bergman, J. W., Jensen, E. J., Pfister, L., and Yang, Q.: Seasonal differences of vertical-transport efficiency in the tropical tropopause layer: On the interplay between tropical deep convection, largescale vertical ascent, and horizontal circulations, J. Geophys. Res., 117, D05302, doi:10.1029/2011JD016992, 2012.

Brabec, M., Wienhold, F. G., Luo, B. P., Vömel, H., Immler, F., Steiner, P., Hausammann, E., Weers, U., and Peter, T.: Particle backscatter and relative humidity measured across cirrus clouds and comparison with microphysical cirrus modelling, Atmos. Chem. Phys., 12, 9135-9148, doi:10.5194/acp-12-9135-2012, 2012.

Bukowiecki, N., Zieger, P., Weingartner, E., Jurányi, Z., Gysel, M., Neininger, B., Schneider, B., Hueglin, C., Ulrich, A., Wichser, A., Henne, S., Brunner, D., Kaegi, R., Schwikowski, M., Tobler, L., Wienhold, F. G., Engel, I., Buchmann, B., Peter, T., and Baltensperger, U.: Ground-based and airborne in-situ measurements of the Eyjafjallajökull volcanic aerosol plume in Switzerland in spring 2010, Atmos. Chem. Phys., 11, 10011-10030, doi:10.5194/acp-11-10011-2011, 2011.

Carminati, F., Ricaud, P., Pommereau, J.-P., Rivière, E., Khaykin, S., Attié, J.-L., and Warner, J.: Impact of tropical land convection on the water vapour budget in the tropical tropopause layer, Atmos. Chem. Phys., 14, 6195-6211, doi:10.5194/acp-14-61952014, 2014.

Cirisan, A., Luo, B. P., Engel, I., Wienhold, F. G., Sprenger, M., Krieger, U. K., Weers, U., Romanens, G., Levrat, G., Jeannet, P., Ruffieux, D., Philipona, R., Calpini, B., Spichtinger, P., and Peter, T.: Balloon-borne match measurements of midlatitude cirrus clouds, Atmos. Chem. Phys., 14, 7341-7365, doi:10.5194/acp14-7341-2014, 2014.

Chaboureau, J.-P., Cammas, J.-P., Duron, J., Mascart, P. J., Sitnikov, N. M., and Voessing, H.-J.: A numerical study of tropical crosstropopause transport by convective overshoots, Atmos. Chem. Phys., 7, 1731-1740, doi:10.5194/acp-7-1731-2007, 2007.

Chemel, C., Russo, M. R., Pyle, J. A., Sokhi, R. S., and Schiller, C.: Quantifying the imprint of a severe hector thunderstorm during ACTIVE/SCOUT-O3 onto the water content in the upper troposphere/lower stratosphere, Mon. Weather Rev., 137, 2493-2514, doi:10.1175/2008MWR2666.1, 2009.

Corti, T., Luo, B. P., de Reus, M., Brunner, D., Cairo, F., Mahoney, M. J., Martucci, G., Matthey, R., Mitev, V., dos Santos, F. H., Schiller, C., Shur, G., Sitnikov, N. M., Spelten, N., Vossing, H. J., Borrmann, S., and Peter, T.: Unprecedented evidence for deep convection hydrating the tropical stratosphere, Geophys. Res. Lett., 35, L10810, doi:10.1029/2008GL033641, 2008.

Danielsen, E. F.: In situ evidence of rapid, vertical, irreversible transport of lower tropospheric air into the lower stratosphere by convective cloud turrets and by large scale up welling in tropical cyclones, J. Geophys. Res., 98, 8665-8681, 1993.

Dee, D. P., Uppala, S. M., Simmons, A. J., Berrisford, P., Poli, P., Kobayashi, S., Andrae, U., Balmaseda, M. A., Balsamo, G., Bauer, P., Bechtold, P., Beljaars, A. C. M., van de Berg, L., Bidlot, J., Bormann, N., Delsol, C., Dragani, R., Fuentes, M., Geer, A. J., Haimberger, L., Healy, S. B., Hersbach, H., Holm, E. V.,
Isaksen, L., Kallberg, P., Kohler, M., Matricardi, M., McNally, A. P., Monge-Sanz, B. M., Morcrette, J.-J., Park, B.-K., Peubey, C., de Rosnay, P., Tavolato, C., Thepaut, J.-N., and Vitart, F.: The ERA-Interim reanalysis: configuration and performance of the data assimilation system, Q. J. Roy. Meteor. Soc., 137, 553-597, doi:10.1002/qj.828, 2011.

de Reus, M., Borrmann, S., Bansemer, A., Heymsfield, A. J., Weigel, R., Schiller, C., Mitev, V., Frey, W., Kunkel, D., Kürten, A., Curtius, J., Sitnikov, N. M., Ulanovsky, A., and Ravegnani, F.: Evidence for ice particles in the tropical stratosphere from in-situ measurements, Atmos. Chem. Phys., 9, 6775-6792, doi:10.5194/acp-9-6775-2009, 2009.

Dessler, A. E., Schoeberl, M. R., Wang, T., Davis, S. M., and Rosenlof, K. H.: Stratospheric water vapor feedback, P. Natl. Acad. Sci. USA, 110, 8087-18091, 2013.

Durry, G., Amarouche, N., Joly, L., Liu, X., Parvitte, B., and Zeninari, $\mathrm{V}$.: Laser diode spectroscopy of $\mathrm{H}_{2} \mathrm{O}$ at $2.63 \mu \mathrm{m}$ for atmospheric applications, Appl. Phys. B, 90, 573-580, 2008.

Fueglistaler, S., Dessler, A. E., Dunkerton, T. J., Folkins, I., Fu, Q., and Mote, P. W.: The tropical tropopause layer, Rev. Geophys., 47, RG1004, doi:10.1029/2008RG000267, 2009.

Gettelman, A. and Forster, P. M.: A climatology of the tropical tropopause layer, J. Meteorol. Soc. Jpn., 80, 911-924, 2002.

Ghysels, M., Gomez, L., Cousin, J., Amarouche, N., Jost, H., and Durry, G.: Spectroscopy of $\mathrm{CH}_{4}$ with a Difference Frequency Generation laser at 3.3 micron for atmospheric applications, Appl. Phys. B, 104, 989-1000, 2011.

Ghysels, M., Gomez, L., Cousin, J., Tran, H., and Durry, G.: Temperature dependence of air-broadening, air-narrowing and linemixing coefficients of the methane $(\mathrm{R}(6), v 3)$ manifold for atmospheric applications, J. Quant. Spectrosc. Ra., 133, 206-216, 2014.

Ghysels, M., Riviere, E. D., Khaykin, S., Stoeffler, C., Amarouche, N., Pommereau, J.-P., Held, G., and Durry, G.: Intercomparison of in situ water vapor balloon-borne measurements from PicoSDLA $\mathrm{H}_{2} \mathrm{O}$ and FLASH-B in the tropical UTLS, Atmos. Meas. Tech., 9, 1207-1219, doi:10.5194/amt-9-1207-2016, 2016.

Grosvenor, D. P., Choularton, T. W., Coe, H., and Held, G.: A study of the effect of overshooting deep convection on the water content of the TTL and lower stratosphere from Cloud Resolving Model simulations, Atmos. Chem. Phys., 7, 4977-5002, doi:10.5194/acp-7-4977-2007, 2007.

Holton, J. R. and Gettelman, A.: Horizontal transport and the dehydration of the stratosphere, Geophys. Res. Lett., 28, 2799-2802, 2001.

Homan, C. D., Volk, C. M., Kuhn, A. C., Werner, A., Baehr, J., Viciani, S., Ulanovski, A., and Ravegnani, F.: Tracer measurements in the tropical tropopause layer during the AMMA/SCOUTO3 aircraft campaign, Atmos. Chem. Phys., 10, 3615-3627, doi:10.5194/acp-10-3615-2010, 2010.

Iwasaki, S., Shibata, T., Nakamoto, J., Okamoto, H., Ishimoto, H., and Kubota, H.: Characteristics of deep convection measured by using the A-train constellation, J. Geophys. Res., 115, D06207, doi:10.1029/2009JD013000, 2010.

Jensen, E. J., Ackerman, A. S., Smith J. A.: Can overshooting convection dehydrate the tropical tropopause layer?, J. Geophys. Res., 112, D11209, doi:10.1029/2006JD007943, 2007.

Kelly, K. K., Proffitt, M. H., Chan, K. R., Loewenstein, M., Podolske, J. R., Strahan, S. E., Wilson, J. C., and Kley, D.: Water 
vapour and cloud water measurements over Darwin during the STEP 1987 tropical mission, J. Geophys. Res., 98, 8713-8723, 1993.

Khaykin, S., Pommereau, J.-P., Korshunov, L., Yushkov, V., Nielsen, J., Larsen, N., Christensen, T., Garnier, A., Lukyanov, A., and Williams, E.: Hydration of the lower stratosphere by ice crystal geysers over land convective systems, Atmos. Chem. Phys., 9, 2275-2287, doi:10.5194/acp-9-2275-2009, 2009.

Khaykin, S. M., Pommereau, J.-P., and Hauchecorne, A.: Impact of land convection on temperature diurnal variation in the tropical lower stratosphere inferred from COSMIC GPS radio occultations, Atmos. Chem. Phys., 13, 6391-6402, doi:10.5194/acp-136391-2013, 2013a.

Khaykin, S. M., Engel, I., Vömel, H., Formanyuk, I. M., Kivi, R., Korshunov, L. I., Krämer, M., Lykov, A. D., Meier, S., Naebert, T., Pitts, M. C., Santee, M. L., Spelten, N., Wienhold, F. G., Yushkov, V. A., and Peter, T.: Arctic stratospheric dehydration - Part 1: Unprecedented observation of vertical redistribution of water, Atmos. Chem. Phys., 13, 11503-11517, doi:10.5194/acp13-11503-2013, 2013b.

Konopka, P., Grooß, J.-U., Ploeger, F., and Muller, R.: Annual cycle of horizontal in-mixing into the lower tropical stratosphere, J. Geophys. Res., 114, D19111, doi:10.1029/2009JD011955, 2009.

Konopka, P., Grooß, J.-U., Günther, G., Ploeger, F., Pommrich, R., Müller, R., and Livesey, N.: Annual cycle of ozone at and above the tropical tropopause: observations versus simulations with the Chemical Lagrangian Model of the Stratosphere (CLaMS), Atmos. Chem. Phys., 10, 121-132, doi:10.5194/acp-10-121-2010, 2010

Livesey, N. J., Read, W. G., Wagner, P. A., Froidevaux, L., Lambert, A., Manney, G. L., Millán-Valle, L. F., Pumphrey, H. C., Santee, M. L., Schwartz, M. J., Wang, S., Fuller, R. A., Jarnot, R. F., Knosp, B. W., and Martinez, E.: Version 4.2x Level 2 data quality and description document, Tech. Rep. JPL D-33509, NASA Jet Propulsion Laboratory, version 4.2x-1.0, 2015.

Liu, C. and Zipser, E. J.: Global distribution of convection penetrating the tropical tropopause, J. Geophys. Res., 110, D23104, doi:10.1029/2005JD006063, 2005.

Liu, X. M., Rivière, E. D., Marécal, V., Durry, G., Hamdouni, A., Arteta, J., and Khaykin, S.: Stratospheric water vapour budget and convection overshooting the tropopause: modelling study from SCOUT-AMMA, Atmos. Chem. Phys., 10, 8267-8286, doi:10.5194/acp-10-8267-2010, 2010.

Marcy, T. P., Popp, P. J., Gao, R. S., Fahey, D. W., Ray, E. A., Richard, E. C., Thompson, T. L., Atlas, E. L., Loewenstein, M., Wofsy, S. C., Park, S., Weinstock, E. M., Swartz, W. H., and Mahoney, M. J.: Measurements of trace gases in the tropical tropopause layer, Atmos. Environ., 41, 7253-7261, doi:10.1016/j.atmosenv.2007.05.032, 2007.

Massie, S. T., Gille, J., Craig, C., Khosravi, R., Barnett, J., Read, W., and Winker, D.: HIRDLS and CALIPSO observations of tropical cirrus, J. Geophys. Res., 115, D00H11, doi:10.1029/2009JD012100, 2010.

McKenna, D. S., Grooß, J.-U., Günther, G., Konopka, P., Müller, R., Carver, G., and Sasano, Y.: A new Chemical Lagrangian Model of the Stratosphere (CLaMS): 2. Formulation of chemistry scheme and initialization, J. Geophys. Res., 107, 4256, doi:10.1029/2000JD000113, 2002.
Nielsen, J. K., Larsen, N., Cairo, F., Di Donfrancesco, G., Rosen, J. M., Durry, G., Held, G., and Pommereau, J. P.: Solid particles in the tropical lowest stratosphere, Atmos. Chem. Phys., 7, 685695, doi:10.5194/acp-7-685-2007, 2007.

Ploeger, F., Konopka, P., Müller, R., Fueglistaler, S., Schmidt, T., Manners, J. C., Grooß, J.-U., Günther, G., Forster, P. M., and Riese, M.: Horizontal transport affecting trace gas seasonality in the Tropical Tropopause Layer TTL, J. Geophys. Res., 117, 09303, doi:10.1029/2011JD017267, 2012.

Pommrich, R., Müller, R., Grooß, J.-U., Konopka, P., Ploeger, F., Vogel, B., Tao, M., Hoppe, C. M., Günther, G., Spelten, N., Hoffmann, L., Pumphrey, H.-C., Viciani, S., D’Amato, F., Volk, C. M., Hoor, P., Schlager, H., and Riese, M.: Tropical troposphere to stratosphere transport of carbon monoxide and long-lived trace species in the Chemical Lagrangian Model of the Stratosphere (CLaMS), Geosci. Model Dev., 7, 2895-2916, doi:10.5194/gmd7-2895-2014, 2014.

Randel, W. J. and Jensen, E. J.: Physical processes in the tropical tropopause layer and their roles in a changing climate, Nat. Geosci., 6, 196-176, 2013.

Randel, W. J., Zhang, K., and Fu, R.: What controls stratospheric water vapor in the NH summer monsoon regions?, J. Geophys. Res.-Atmos., 120, 7988-8001, doi:10.1002/2015JD023622, 2015.

Ricaud, P., Barret, B., Attié, J.-L., Motte, E., Le Flochmoën, E., Teyssèdre, H., Peuch, V.-H., Livesey, N., Lambert, A., and Pommereau, J.-P.: Impact of land convection on tropospherestratosphere exchange in the tropics, Atmos. Chem. Phys., 7, 5639-5657, doi:10.5194/acp-7-5639-2007, 2007.

Ricaud, P., Pommereau, J.-P., Attié, J.-L., Le Flochmoën, E., El Amraoui, L., Teyssèdre, H., Peuch, V.-H., Feng, W., and Chipperfield, M. P.: Equatorial transport as diagnosed from nitrous oxide variability, Atmos. Chem. Phys., 9, 8173-8188, doi:10.5194/acp9-8173-2009, 2009.

Riese, M., Ploeger, F., Rap, A., Vogel, B., Konopka, P., Dameris, M., and Forster, P.: Impact of uncertainties in atmospheric mixing on simulated UTLS composition and related radiative effects, J. Geophys. Res.-Atmos., 117, 2156-2202, doi:10.1029/2012JD017751, 2012.

Sargent, M. R., Smith, J. B., Sayres D. S., and Anderson, J. G.: The roles of deep convection and extratropical mixing in the tropical tropopause layer: An in situ measurement perspective, J. Geophys. Res.-Atmos., 119, 12355-12371, doi:10.1002/2014JD022157, 2014.

Schiller, C., Grooß, J.-U., Konopka, P., Plöger, F., Silva dos Santos, F. H., and Spelten, N.: Hydration and dehydration at the tropical tropopause, Atmos. Chem. Phys., 9, 9647-9660, doi:10.5194/acp-9-9647-2009, 2009.

Solomon, S., Rosenlof, K. H., Portmann, R.W., Daniel, J. S., Davis, S. M., Sanford, T. J., and Plattner, G. K.: Contributions of tratospheric water vapor to decadal changes in the rate of global warming, Science, 327, 1219-1223, 2010.

Stein, A. F., Draxler, R. R., Rolph, G. D., Stunder, B. J. B., Cohen, M. D., and Ngan, F.: NOAA's HYSPLIT atmospheric transport and dispersion modeling system, B. Am. Meteorol. Soc., 96, 2059-2077, doi:10.1175/BAMS-D-14-00110.1, 2015.

Vernier, J. P., Pommereau, J. P., Garnier, A., Pelon, J., Larsen, N., Nielsen, J., Christensen, T., Cairo, F., Thomason, L. W., Leblanc, T., and McDermid, I. S.: The tropical stratospheric 
aerosol layer from CALIPSO lidar observations, J. Geophys. Res., 114, D00H10, doi:10.1029/2009JD011946, 2009.

Vernier, J.-P., Pommereau, J.-P., Thomason, L. W., Pelon, J., Garnier, A., Deshler, T., Jumelet, J., and Nielsen, J. K.: Overshooting of clean tropospheric air in the tropical lower stratosphere as seen by the CALIPSO lidar, Atmos. Chem. Phys., 11, 96839696, doi:10.5194/acp-11-9683-2011, 2011.

Vernier, J.-P., Fairlie, T. D., Natarajan, M., Wienhold, F. G., Bian, J., Martinsson, B. G., Crumeyrolle, S., Thomason, L. W., and Bedka, K.: Increase in upper tropospheric and lower stratospheric aerosol levels and its potential connection with Asian Pollution, J. Geophys. Res.-Atmos., 120, 1608-1619, doi:10.1002/2014JD022372, 2015.
Winker, D. M., Vaughan, M. A., Omar, A. H., Hu, Y., Powell, K. A., Liu, Z., Hunt, W. H., and Young, S. A.: Overview of the CALIPSO Mission and CALIOP Data Processing Algorithms, J. Atmos. Ocean. Tech., 26, 2310-2323, doi:10.1175/2009JTECHA1281.1, 2009.

Yushkov, V., Astakhov V., and Merkulov, S.: Optical balloon hygrometer for upper-troposphere and stratosphere water vapor measurements, in: Proceedings SPIE 3501, Optical Remote Sensing of the Atmosphere and Clouds, Beijing, China, 14 September 1998, 439-445, 1998. 